Gut, 1986, 27, 587-588

Case report

\title{
Recurrent typhoid in an HTLV-III antibody positive man
}

\author{
D R J JARRETT AND R ZEEGEN \\ From the Department of Gastroenterology, St Stephen's Hospital, London
}

SUMMARY A case of recurrent typhoid fever in a homosexual man with antibodies to human $\mathrm{T}$ cell lymphotropic virus-III (HTLV-III) and impaired cell mediated immunity is reported: we believe the first report of Salmonella typhi infection in association with HTLV-III disease.

Typhoid fever is an acute systemic disease caused by infection with Salmonella typhi. It usually results from ingestion of food or water contaminated with the organism. Outbreaks in the United Kingdom are rare; the infection is usually acquired during foreign travel. The organism is nearly always sensitive to chloramphenicol but in spite of treatment typhoid may recur, often a few weeks after symptoms have resolved, in up to $10 \%$ of cases. Non-typhoidal salmonella infections are more common and have recently been reported as early infections in the acquired immunodeficiency syndrome (AIDS).

\section{Case report}

A 44 year old male designer presented in November 1984 with a nine day history of fever, nocturnal sweating, rigors, a dry cough and colicky abdominal pains. For the three days before admission he had had profuse diarrhoea initially preceded by constipation. There was no history of foreign travel nor contact with any cases of diarrhoea. He was a disciple of the 'macrobiotic' diet but otherwise had had no dietary indiscretion. He had had syphilis, gonorrhea, and hepatitis B in the past, and in 1983 herpes zoster involving the left L1 dermatome. There was no history of gall bladder disease. He was homosexual and last had intercourse with an Iraqi man in a local Turkish baths four weeks before admission.

On examination he was pyrexial $\left(39 \cdot 5^{\circ} \mathrm{C}\right)$ and drowsy. There were no skin lesions. The only physical finding was generalised abdominal tenderness. $\mathrm{He}$ was not anaemic $(\mathrm{Hb} 13.5 \mathrm{~g} / \mathrm{dl})$ and the white cell count was $6.3 \times 10^{9} / 1$ with $9 \%$ lymphocytes and $89 \%$ neutrophils showing toxic granulation. Blood and

Address for correspondence: Dr D R J Jarrett, Department of Gastroenterology, St Stephen's Hospital, Fulham Road, London SW10.

Received for publication 16 August 1985. stool cultures grew Salmonella typhi sensitive to chloramphenicol and he was started on $500 \mathrm{mg}$ of chloramphenicol orally five times a day. His fever, diarrhoea, cough, and abdominal pains gradually settled. Repeated stool cultures at this stage failed to grow Salmonella typhi. After two weeks his antibiotics were stopped and he was discharged symptom free. Ten days later he was readmitted with a seven day history of fever, diarrhoea, and abdominal pains. Salmonella typhi was again isolated from blood cultures and bone marrow but not from the faeces. He had an absolute lymphopaenia of $0.6 \times 10^{9} / 1$. Bone marrow showed normal granulopoeisis but decreased erythropoeisis consistent with acute infection. He was given oral chloramphenicol in the same dose as before for 10 days followed by oral amoxycillin $1500 \mathrm{mg}$ thrice daily for three weeks. His symptoms again resolved after a few days and he was discharged three weeks later and has since remained well.

We were unable to trace his recent sexual partners. We failed to isolate Salmonella typhi from food in his home or from his specialist health food shops. Samples of water from the Turkish bath grew no Salmonella. He showed anergy to intradermal tuberculin, candida, trychophyton, mumps and tetanus antigens. He had a persistent absolute lymphopaenia, decreased T-helper cells and abnormal T-helper/T-suppressor ratio (Table).

Table Lymphocyte subsets

\begin{tabular}{|c|c|c|c|}
\hline & November 84 & February 85 & Normal range \\
\hline Lymphocyte count & 0.9 & 1.4 & $(1.5-4) \times 10^{9} / 1$ \\
\hline Total T-lymphocytes & 0.41 & 0.79 & - \\
\hline T-helper cells & 0.20 & 0.21 & $>0.53 \times 10^{9} / 1$ \\
\hline T-suppressor cells & $0 \cdot 19$ & 0.62 & - \\
\hline $\begin{array}{l}\text { Helper/suppressor } \\
\text { ratio }\end{array}$ & 1.05 & 0.33 & $>1.2$ \\
\hline
\end{tabular}


Immunoglobulin levels were normal. He was HTLV-III antibody positive.

\section{Discussion}

Typhoid fever is usually acquired by ingesting food or water contaminated by Salmonella typhi. Two cases of sexual transmission of Salmonella typhi have been described in male homosexuals. ${ }^{1}$ Amongst the male homosexual population enteric infections such as shigellosis, salmonellosis, campylobacter enteritis, amoebiasis, giardiasis, and enterobiasis are common and result from increased promiscuity and from the nature of homosexual intercourse itself. ${ }^{2-4}$ We were unable to confirm a food source of infection in our patient nor trace his recent sexual contacts.

Cell mediated immunity is thought to be important in the protection against salmonella infections. Salmonella septicaemia has been reported in patients with leukaemia, ${ }^{5}$ Hodgkin's disease, ${ }^{6}$ malignancy, ${ }^{7}$ and corticosteroid therapy. ${ }^{8}$ It is becoming increasingly recognised that persistent Salmonella typhimurium bacteraemia is an early infection in the acquired immunodeficiency syndrome (AIDS) and may present many months before the classical opportunistic infections and/or Kaposi's sarcoma are manifest. ${ }^{9-12}$ Recently the human T-cell lymphotropic virus-III (HTLV-III) has been identified as the probable causative organism of AIDS. ${ }^{13} 14$ Antibodies reactive against antigens of HTLV-III are found in $88 \%$ of patients with AIDS and $79 \%$ of homosexual men with symptoms and signs which often preceed AIDS yet are present in less than $1 \%$ of people with no risk factors for AIDS. ${ }^{15}$ HTLV-III has an affinity for the helper $T$-cell and destruction of these contributes to the impaired immunity in AIDS. Infection with HTLV-III gives a spectrum of disease ranging from no symptoms through persistent generalised lymphadenopathy and 'pre-AIDS' to AIDS itself. Our patient did not fit the criteria for AIDS set down by the Centre for Disease Control in the USA. He did have persistent lymphopaenia, low T-helper count, low T-helper/T-suppressor ratio and cutaneous anergy, all of which are found in AIDS. ${ }^{16}$ Although non-typhoid salmonella bacteraemia (especially Salmonella typhimurium) is well recognised as an early infection in AIDS this is the first report of recurrent Salmonella typhi infection associated with HTLV-III disease.

\section{References}

1 Dritz SK, Braff EH. Sexually transmitted typhoid fever. N Engl J Med 1977; 296: 1359-60.

2 Baker RW, Peppercorn MA. Gastrointestinal ailments of homosexual men. Medicine 1982; 61: 390-405.

3 William DC. Hepatitis and other sexually transmitted diseases in gay men and lesbians. Sexual Transm Dis 1981; 8: 330-2.

4 Felman YM, Ricciardi NB. Sexually transmitted enteric diseases. Bull NY Acad Med 1979; 55: 533-9.

5 Wolfe MS, Armstrong D, Louria DB, Blevins A. Salmonellosis in patients with neoplastic disease: a review of 100 episodes at Memorial Cancer Centre over a 13 year period. Arch Intern Med 1971; 128: 546-54.

6 Heineman HS, Jansen WN, Cooper WM, Braude AI. Hodgkin's disease and Salmonella typhimurium infection. JAMA 1964; 188: 632-4.

7 Han T, Sokal JE, Neter E. Salmonellosis in disseminated malignant disease: a seven year review (19591965). N Engl J Med 1967; 276: 1045-52.

8 Black PH, Kunz LJ, Swartz MN. Salmonellosis: a review of some unusual aspects. N Engl J Med 1960; 262: $864-70$.

9 Bottone EJ, Wormser GP, Duncanson FP. Nontyphoidal Salmonella bacteremia as an early infection in acquired immunodeficiency syndrome. Diagn Microbiol Infect Dis 1984; 2: 247-50.

10 Smith PD, Macher AM, Bookman MA et al. Salmonella Typhimurium enteritis and bacteraemia in the acquired immunodeficiency syndrome. Ann Intern Med 1985; 102: 207-9.

11 Glaser JB, Morton-Kute L, Berger SR et al. Recurrent Salmonella typhimurium bacteraemia associated with the acquired immunodeficiency syndrome. Ann Intern Med 1985; 102: 189-93.

12 Jacobs JL, Gold JWM, Murray HW, Roberts RB, Armstrong D. Salmonella infections in patients with the acquired immunodeficiency syndrome. Ann Intern Med 1985; 102: 186-8.

13 Gallo RC, Salahuddin SZ, Popovic M et al. Frequent detection and isolation of cytopathic retroviruses (HTLV-III) in patients with AIDS and at risk of AIDS. Science 1984; 224: 500-2.

14 Popovic M, Sarngadharan MG, Read E, Gallo RC. Detection, isolation and continuous production of cytopathic retroviruses (HTLV-III) from patients with AIDS and pre-AIDS. Science 1984; 224: 497-500.

15 Sarngadharan MG, Popovic M, Bruch L, Schiipbach J, Gallo RC. Antibodies reactive with human T-lymphotrophic retroviruses (HTLV-III) in the serum of patients with AIDS. Science 1984; 224: 506-8.

16 Lane HC. Immunologic abnormalities in the acquired immunodeficiency syndrome, pp 98-9. In: Fauci AS, moderator. Acquired immunodeficiency syndrome: epidemiologic, clinical, immunologic and therapeutic considerations. Ann Intern Med 1984; 100: 92-106. 